\title{
Quality characteristics and antioxidant activity of sponge cake with cabbage powder
}

\author{
Sook-Young $\mathrm{Kim}^{1}$, $\mathrm{Ki}-\mathrm{Ju} \mathrm{Kim}^{2 *}$ \\ ${ }^{1}$ Department of Food Science and Technology, Yeungnam University, Gyeongsan 38541, Korea \\ ${ }^{2}$ Department of Vocational Rehabilitation, Daegu Future College, Gyeongsan 38607, Korea
}

\section{양배추 분말을 첨가한 스펀지 케이크의 품질특성 및 항산화 활성}

\author{
김숙영 ${ }^{1} \cdot$ 김기주 ${ }^{2 *}$ \\ ${ }^{1}$ 영남대학교 식품공학과, ${ }^{2}$ 대구미래대학교 특수직업재활과
}

\begin{abstract}
The purpose of this study was to investigate the quality characteristics, antioxidant activities and sensory properties of sponge cake with cabbage powder (CP). Physicochemical and sensory properties of sponge cake with different amount $(0 \%, 5 \%, 10 \%$, and $15 \%)$ of $\mathrm{CP}$ were examined. As the increase in the amount of CP addition, the specific gravity and baking loss rate were increased, whereas the color of the cake crumb and crust, volume index and specific volume were decreased $(\mathbf{p}<\mathbf{0 . 0 5})$. The symmetry and uniformity index of the sponge cake were not affected by the addition of CP $(5-15 \%)(p<0.05)$. The hardness was significantly increased while by $C P$ addition cohesiveness was decreased $(\mathbf{p}<0.05)$. The springiness, gumminess and brittleness were not changed by $\mathbf{C P}$ addition $(\mathbf{p}<0.05)$. The total polyphenolic, DPPH radical scavenging activities and reducing power were significantly increased by addition of $\mathrm{CP}$ at high concentrations $(\mathbf{p}<0.05)$. In the sensory evaluation, addition of $\mathrm{CP}$ significantly degraded the panel preference related to the color, flavor and texture of the sponge cake. However, the highest point were given to sponge cakes containg $5-10 \%$ of $C P$ in taste and overall acceptance $(p<0.05)$. These data suggested that adding $5 \%$ of $\mathrm{CP}$ is the optimal concentration overall for making sponge cake. However, the sponge cake with $10 \%$ of $\mathrm{CP}$ is recommended in order to maximize antioxidant activity, the sponge cake was the best when contained $5 \% \mathrm{CP}$ and the sponge cake prepared with the addition of $10 \% \mathrm{CP}$ was recommended to use due to its advantages in functional property.
\end{abstract}

Key words : sponge cake, cabbage powder, sensory evaluation, antioxidant activity, texture

\section{서 론}

경제 성장과 더불어 식생활이 점차 간편해지고 서구화되 면서 주식 대용으로 제과제빵의 소비가 높은 비중을 차지하 고 있다(1). 최근에는 건강에 대한 폭넓은 관심으로 기존의 재료보다는 다양한 생리활성 물질을 갖고 있는 천연재료를

*Corresponding author. E-mail : homebakekim@daum.net Phone : 82-53-810-9448, Fax : 82-53-801-3732

Received 21 March 2017; Revised 19 April 2017; Accepted 19 April 2017.

Copyright (c) The Korean Society of Food Preservation. All rights reserved.
활용한 건강기능성 식품의 수요가 점차 높아지는 추세이다 (2). 특히 식품으로부터 유래하는 생리활성을 가지는 기능 성 식품에 대한 연구가 최대의 관심사로 식품의 기능성이라 는 과제가 대두되어 왔다. 각종 질병에 대한 예방이 가능한 생리활성물질을 함유한 천연재료에 대한 연구는 기능성 식품으로서의 이용 가능성 측면에서도 그 의미가 크다고 할 수 있을 것이다. 또한 소비자들의 식생활 패턴은 건강에 좋은 식품을 구매하고 소비하는 경향으로 변화되고 있다. 제과제빵 산업에서도 밀가루 외에 다른 곡물이나 천연 식품 소재를 첨가하여 기능성이 강조된 다양한 제품이 시판되고 있으며 소비자들로부터 좋은 반응을 얻고 있다.

기능성 천연재료를 첨가한 스펀지 케이크 제조 연구는 
조분말, 김분말, 마가루, 새송이 버섯분말 등(3-6)의 연구가 있으며 $\operatorname{Kim}$ 등(7)은 브로콜리 분말을 첨가한 스펀지 케이 크의 연구에서 가장 적절한 대체비율은 $5 \%$, 브로콜리 분말 의 생리기능성을 고려할 때는 $10 \%$ 까지도 가능하다고 보고 하였고 Lee 등(8)은 스펀지 케이크에 관능적 품질과 건강 기능성 효과 등을 고려할 때 솔잎분말을 $2-4 \%$ 첨가가 가장 적절한 것으로 판단하였다. $\mathrm{Kim}(9)$ 은 무청 분말을 첨가한 스펀지 케이크의 품질특성 연구에서 가장 적절한 대체비율 은 $5 \%$ 로 제시하였고 무청분말 $10 \%$ 까지 첨가도 가능할 것 으로 보고하였다.

스펀지 케이크는 거품형 케이크(form type cake)의 가장 기본되는 제품으로서 데커레이션 케이크, 젤리롤 케이크, 프티푸르 등 많은 제품에 응용되어지는 다양성이 높은 제품 이다. 또한 스펀지 케이크는 맛이 너무 단순하여 그 자체만 으로 판매하는 경우는 드물며 맛과 모양을 부가시켜 제품의 품질을 향상시키는 경우가 많다.

양배추(Brassica oleracea L.)의 원산지는 지중해 연안이 며 십자화과의 채소로써 식이섬유, 비타민, 미네랄 및 파이 토케미컬(phytochemical)을 다량 함유하고 있다(10). 양배 추에는 지혈작용을 하는 비타민 $\mathrm{K}$ 와 항궤양성의 비타민 $\mathrm{U}$ 가 풍부하게 함유하고 있어 위궤양 치료에 효과가 있으며 (11-13) 수분 $93.3 \%$, 단백질 $0.6 \%$, 지방 $0.1 \%$, 당질 $5.6 \%$, 총 식이섬유 $1.4 \%$, 회분 $0.6 \%$ 등이 함유되어 있다(14). 또한 양배추는 caffeic acid, ferulic acid, p-coumaric acid 등을 비롯하여 항산화제 성분을 함유하고 있다 $(15,16)$. 양배추는 주로 생것 또는 삶거나 데치는 등의 방법으로 각종 요리에 사용되고 있으며 양배추를 첨가한 연구로는 설기떡, 증편, 물김치 등(17-19)에 관한 연구가 있으며 제과제빵에 대한 연구는 양배추 분말 첨가가 제빵 적성에 미치는 영향(20), 양배추 분말을 대체한 시폰 케이크 제조와 항산화 활성(21) 등으로 미비한 실정이다.

본 연구는 생리적 기능성이 우수한 양배추 분말을 다양 한 식품에 폭넓게 사용하기 위한 응용 연구로 양배추 분말 을 5-15\% 첨가한 스펀지 케이크를 제조하고 케이크 품질특 성 및 항산화 활성을 조사하여 적정 첨가량의 수준을 제시 하고자 하였다.

\section{재료 및 방법}

\section{실험재료}

본 연구에 사용된 밀가루는 박력분 (주대한제분(Busan, Korea), 설탕은 삼양사(Sungnam, Korea), 계란은 농협 하나 로 마트(Gyeongsan, Korea), 소금은 천일염(Sinan, Korea), 옥수수기름은 동원F\&B(Haenam, Korea), 양배추 분말(수분 함량 $3.28 \%$ )은 정우당(Seoul, Korea) 제품으로 시중에서 구 입하여 사용하였다.
스펀지 케이크의 제조

양배추 분말을 첨가한 스펀지 케이크의 재료 배합 및 제조는 $\mathrm{Yi}$ 등(22)의 방법을 일부 변형하여 제조하였으며 배합비는 Table 1 과 같다. 양배추 분말은 박력분 중량을 기준으로 $0-15 \%$ 를 첨가하였고 케이크 제조는 공립법으로 설탕의 용해성을 증가시키고 계란의 기포성을 향상시키며 제품의 부피를 크게 하기 위하여 더운 방법(hot mixing method)을 사용하였다. 먼저 수직형 반죽기(Model NVM-95, Dae Young Co., Seoul, Korea)를 사용하여 믹서 볼에 전란 (whole egg)을 넣고 골고루 풀어 준 다음 설탕과 소금을 첨가하여 중탕으로 $43^{\circ} \mathrm{C}$ 가 될 때까지 가온하고 중속 30 초, 고속으로 6 분, 다시 중속으로 2 분간 혼합하여 기포형성이 최적 상태로 형성될 때까지 휘핑하였다. 여기에 밀가루와 양배추 분말 첨가비율을 달리한 각각의 혼합분을 체로 쳐서 넣고 골고루 혼합한 후 중탕으로 데운 옥수수기름을 반죽에 넣고 옥수수기름이 바닥에 가라앉지 않도록 혼합하여 반죽 을 완료하였다. 원형 케이크 팬(안쪽직경 $21.2 \mathrm{~cm}$, 깊이 $4.5 \mathrm{~cm}$, 안쪽부피 $1,590 \mathrm{~mL}$ )에 반죽을 $460 \mathrm{~g}$ 넣고 윗불 $180^{\circ} \mathrm{C}$, 아랫불 $160^{\circ} \mathrm{C}$ 로 예열된 오븐(Model FDO-7102, Dae Young Co., Seoul, Korea)에서 28분간 구웠다. 케이크는 실 온에서 1 시간 방냉한 후 폴리에틸렌 필름으로 포장하여 실험에 사용하였다.

Table 1. Formulations of sponge cakes prepared with cabbage powder

\begin{tabular}{cccccc}
\hline \multirow{2}{*}{ Ingredients $(\mathrm{g})$} & \multirow{2}{*}{$(\%)$} & Control & \multicolumn{3}{c}{ Cabbage powder content $(\%)$} \\
\cline { 4 - 6 } & & & 5 & 10 & 15 \\
\hline Wheat flour & $100^{1)}$ & 500 & 475 & 450 & 425 \\
Whole egg & 180 & 900 & 900 & 900 & 900 \\
Sugar & 120 & 600 & 600 & 600 & 600 \\
Salt & 1 & 5 & 5 & 5 & 5 \\
Corn oil & 20 & 100 & 100 & 100 & 100 \\
Cabbage powder & Variable & 0 & 25 & 50 & 75 \\
\hline
\end{tabular}

${ }^{1)}$ Baker's percentage.

반죽의 비중

케이크 반죽의 비중(specific gravity)은 AACC method (23)에 따라 반죽이 완성된 후 물의 무게에 대한 최종 케이 크 반죽 무게의 비로 나타내었다.

\section{색도 및 외관 촬영}

케이크의 crumb과 crust의 색도는 색차계(color difference meter, JS 555, Color Techno System Co., Tokyo, Japan)를 사용하여 시료를 각각 세로 $50 \times 50 \mathrm{~mm}$ 로 잘라 케이크 외부 와 내부의 중앙 부분을 3회 반복 측정하였다. 그 값은 Hunter scale에 의해 케이크의 $\mathrm{L}$ 값(명도), $\mathrm{a}$ 값(적색도), $\mathrm{b}$ 값(황색 도)으로 평균값을 구하였다. 이때 사용한 표준 백색판은 
$\mathrm{L}=99.42, \mathrm{a}=-0.90, \mathrm{~b}=-0.01$ 이었다.

부피지수, 대칭성지수 및 균일성지수

케이크를 실온에서 1 시간 냉각시킨 후 케이크의 외관상 특성 평가로 부피지수(total volume index), 대칭성지수 (symmetry index) 및 균일성지수(uniformity index)를 AACC 방법(24)에 따라 케이크의 중앙 부분을 절단한 후 측정하였 다.

\section{비용적 및 굽기손실율}

케이크의 무게는 오븐에서 꺼낸 즉시 측정하였고 부피는 실온에서 1시간 냉각시킨 후 종자 치환법(25)에 의해 세 개의 시료를 각각 세 번씩 측정하고 반죽의 무게로 나누어 계산하였다. 비용적(specific loaf volume)은 반죽 $1 \mathrm{~g}$ 이 차지 하는 부피로 그 식은 다음과 같다.

$$
\text { 비용적 }(\mathrm{mL} / \mathrm{g})=\frac{\text { 케이크 부피 }}{\text { 반죽 무게 }}
$$

또한 굽기손실율(baking loss $\operatorname{rate}(\%))$ 은 다음과 같은 수 식으로 구하였다.

$$
\text { 굽기 손실률 }(\%)=\frac{\text { 반죽 무게-케이크 무게 }}{\text { 반죽 무게 }} \times 100
$$

\section{조직감}

텍스처(texture)는 rheometer(Compac-100 П, Sun Scientific Co., Ltd., Tokyo, Japan)를 사용하여 5회 반복 측정하여 통계 처리하였다. 시료는 $50 \times 50 \times 50 \mathrm{~mm}$ 의 크기로 잘라서 압착 했을 때 얻어지는 force distance curve로부터 시료의 texture profile analysis(TPA)를 computer로 분석하여 측정하였다. 이때 사용된 탐침은 $\mathrm{P} 20$ 의 원통형을 장착하여 경도, 응집 성, 탄력성, 점착성, 부서짐성을 측정하였다.

\section{항산화 활성}

시료액 제조는 스펀지 케이크 각각의 시료 $5 \mathrm{~g}$ 에 증류수 $45 \mathrm{~mL}$ 를 가하고 $20^{\circ} \mathrm{C}$ 에서 24시간동안 $100 \mathrm{rpm}$ 으로 homogenizer에서 추출한 후 whatman No. 1 여과지로 여과 하여 시료 액으로 사용하였다.

총 폴리페놀 함량(total polyphenol contents)는 Folin-Denis 방법(26)에 따라 측정하였다. $1 \mathrm{mg} / \mathrm{mL}$ 로 농도를 조절한 시료 $0.2 \mathrm{~mL}$ 에 $1 \mathrm{~N}$ Folin-Ciocalteu's Regent(Sigma Co., St. Louis, MO, USA) $1 \mathrm{~mL}$ 를 넣은 후, 실온에서 3분간 반응시켰 다. 반응액에 $10 \% \mathrm{Na}_{2} \mathrm{CO}_{3} 0.8 \mathrm{~mL}$ 을 넣어 실온에서 1시간 반응시킨 후, $765 \mathrm{~nm}$ 에서 흡광도를 측정하였다. 총 폴리페 놀의 함량은 gallic acid(Sigma Co.)를 이용한 표준곡선으로 부터 산출하였다.

$\mathrm{DPPH}$ radical 소거능은 Blois 법(27)에 따라 측정하였다.
농도 별로 제조한 시료 $0.1 \mathrm{~mL}$ 에 $0.15 \mathrm{mM} \mathrm{DPPH}$ 용액 $0.1 \mathrm{~mL}$ 를 가하여 실온에서 30 분간 반응시켜 $518 \mathrm{~nm}$ 에서 흡광도를 측정하였다. DPPH radical 소거능은 시료 첨가구 와 시료 무첨가구의 차이를 백분율로 나타내었다.

$\mathrm{DPPH}$ radical scavenging activity(\%)=1-( $\left.\frac{\text { 시료 첨가구의 흡광도 }}{\text { 시료 무첨가구의 흡광도 }}\right) \times 100$

환원력(reducing power)은 $\mathrm{Mau}$ 등(28) 및 $\mathrm{Seo}$ 등(29)의 방법에 따라 측정하였다. 농도 별로 제조한 시료 $0.25 \mathrm{~mL}$ 에 $0.2 \mathrm{M}$ sodium phosphate buffer( $\mathrm{pH}$ 6.8) $0.25 \mathrm{~mL}$ 와 $1 \%$ potassium ferricianide $0.25 \mathrm{~mL}$ 를 넣어 $50^{\circ} \mathrm{C}$ 에서 20 분간 반 응시키고, $10 \% \mathrm{TCA}$ (Trichloroacetic acid)를 $0.25 \mathrm{~mL}$ 가하였 다. $1,000 \mathrm{rpm}$ 에서 10 분간 원심분리하여 상징액 $0.1 \mathrm{~mL}$ 에 증류수 $0.1 \mathrm{~mL}$ 을 넣고, $0.1 \%$ ferric chloride $0.02 \mathrm{~mL}$ 을 가하 여 $700 \mathrm{~nm}$ 에서 흡광도를 측정하였다. 양성 대조구는 ascorbic $\mathrm{acid}$ 를 사용하였고, 환원력은 흡광도 값으로 비교하였다.

관능검사

케이크의 관능평가는 Civille와 Szczesniak의 방법(30)에 따라 스펀지 케이크의 특성 및 평가 방법에 대하여 충분히 숙지한 제과기술자를 포함한 훈련된 10 명의 패널요원을 대상으로 각 실험구별로 색상(color), 향미(flavor), 맛(taste), 조직감(texture) 그리고 전체적인 기호도(overall acceptance) 에 대하여 7점 채점법을 사용하여 측정하였으며, 7점은 매 우 좋다, 4점은 보통이다, 1점은 매우 나쁘다로 하였다.

\section{통계 처리}

모든 실험결과 통계처리는 Windows용 SPSS 12.0(SPSS Inc., Chicago, IL, USA)을 사용하였으며 분산분석과 Duncan 의 다중검증법으로 유의성을 검정하였다.

\section{결과 및 고찰}

반죽의 비중

양배추 분말을 첨가한 스펀지 케이크 반죽의 비중을 측 정한 결과는 Table 2와 같다. Pyler(31)는 반죽의 비중이 케이크 최종제품에서의 결과를 예측할 수 있으며 비중이 높으면 부피가 작고 조밀한 기공으로 씹힘성이 떨어지며 비중이 낮으면 약하고 부서지기 쉬운 내상을 가지게 된다고

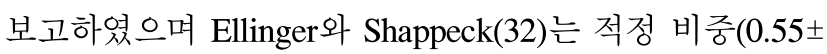
$0.05)$ 즉 적당한 거품형성은 바람직한 품질의 케이크 제조 에 매우 중요하다고 하였다. 본 실험에서는 대조구와 $5 \%$ 첨가구는 유의적 차이를 보이지 않았고 양배추 분말 첨가량 이 증가할수록 비중이 증가하는 경향을 나타내었다. 야콘 분말(33)과 청경채(34)를 첨가한 스펀지 케이크에서도 유 
사한 경향을 나타내었다. 이러한 현상은 양배추 분말 첨가 량이 증가할수록 반죽과정에서 밀가루와 함께 계란 거품의 겉표면에 엉겨 붙어 기포벽을 두껍게 함으로써 유화를 방해 해 기포가 파괴되고, 계란 흰자의 표면변성에 의해 얇은 막 형성이 억제되기 때문으로 판단된다(35,36).

Table 2. Specific gravity of the sponge cake batter containing different amounts of cabbage powder

\begin{tabular}{lcccc}
\hline & \multicolumn{4}{c}{ Cabbage powder content (\%) } \\
\cline { 2 - 5 } & 0 & 5 & 10 & 15 \\
\hline Specific gravity & $0.50 \pm 0.01^{\text {al) }}$ & $0.51 \pm 0.01^{\mathrm{a}}$ & $0.52 \pm 0.01^{\text {ab }}$ & $0.55 \pm 0.01^{\mathrm{b}}$ \\
\hline 1) Values are mean $\pm \mathrm{SD}(\mathrm{n}=3)$, means followed by the same letter in a row do not \\
significantly different $(\mathrm{p}<0.05)$.
\end{tabular}

\section{색도 및 외관촬영}

양배추 분말 첨가량을 달리하여 제조한 스펀지 케이크의 crust와 crumb 색도를 측정한 결과는 Table 3 과 같다. 케이크 crumb의 명도를 나타내는 $\mathrm{L}$ 값은 양배추 분말 첨가량이 증가할수록 82.53-64.68으로 유의적으로 감소하여 어두워 지는 경향을 나타내었다. 적색도를 나타내는 a 값과 황색도 를 나타내는 $\mathrm{b}$ 값은 대조구와 비교하여 양배추 분말 첨가량 이 증가할수록 유의적으로 감소하는 경향을 나타냈다.

스펀지 케이크에 각종 분말을 첨가할 경우, 첨가되는 분 말의 종류와 색, 그리고 굽는 과정 중의 아미노-카아보닐 반응, 열분해에 의한 갈변 정도에 의해 케이크 색도에 영향 을 미치는 것(37)으로 알려져 있는데, 본 실험에서도 양배추 분말 고유의 색상으로 인하여 케이크의 crumb 색도에 영향 을 준 것으로 사료된다. crust의 $\mathrm{L}$ 값은 양배추 분말 첨가량 이 증가할수록 58.32-45.73로 유의적으로 감소하는 경향을 보였으며 적색도와 황색도를 나타내는 $\mathrm{a}$ 값과 $\mathrm{b}$ 값은 양배 추 분말 첨가량이 증가할수록 유의적으로 감소하는 경향을 나타내었다. 이는 케이크 crumb의 색도에서와 같이 crust의 색도에서도 양배추 분말 자체의 색깔이 영향을 주었기 때문

Table 3. Color values of the sponge cakes containing different amounts of cabbage powder

\begin{tabular}{cccccc}
\hline & $\begin{array}{c}\text { Color } \\
\text { values }\end{array}$ & \multicolumn{4}{c}{ Cabbage powder content (\%) } \\
\cline { 3 - 6 } & 0 & 5 & 10 & 15 \\
\hline \multirow{2}{*}{$\begin{array}{c}\text { Crumb } \\
\text { color }\end{array}$} & $\mathrm{L}$ & $82.53 \pm 1.02^{\mathrm{a} 22}$ & $72.55 \pm 0.52^{\mathrm{b}}$ & $69.23 \pm 0.38^{\mathrm{bc}}$ & $64.68 \pm 0.54^{\mathrm{c}}$ \\
& $\mathrm{a}$ & $-0.25 \pm 0.11^{\mathrm{a}}$ & $-2.43 \pm 0.24^{\mathrm{ab}}$ & $-3.13 \pm 0.16^{\mathrm{b}}$ & $-4.56 \pm 0.17^{\mathrm{c}}$ \\
& $\mathrm{b}$ & $33.75 \pm 0.15^{\mathrm{a}}$ & $28.22 \pm 0.22^{\mathrm{b}}$ & $27.68 \pm 0.41^{\mathrm{bc}}$ & $27.13 \pm 0.39^{\mathrm{bc}}$ \\
\hline \multirow{2}{*}{$\begin{array}{c}\text { Crust } \\
\text { color }\end{array}$} & $\mathrm{L}$ & $58.32 \pm 0.71^{\mathrm{a}}$ & $51.58 \pm 0.28^{\mathrm{b}}$ & $47.37 \pm 0.85^{\mathrm{c}}$ & $45.73 \pm 0.98^{\mathrm{d}}$ \\
& $\mathrm{a}$ & $15.66 \pm 0.48^{\mathrm{a}}$ & $12.86 \pm 0.31^{\mathrm{b}}$ & $11.63 \pm 0.28^{\mathrm{bc}}$ & $11.03 \pm 0.23^{\mathrm{c}}$ \\
& $\mathrm{b}$ & $26.65 \pm 0.18^{\mathrm{a}}$ & $21.33 \pm 0.44^{\mathrm{b}}$ & $19.52 \pm 0.50^{\mathrm{bc}}$ & $17.93 \pm 0.34^{\mathrm{c}}$ \\
\hline
\end{tabular}

${ }^{1)}$ L, Lightness (white;+100-black;0); a, redness (red;+100-green;-80); b, yellowness (yellow;+70-blue;-70).

${ }^{2)}$ Values are mean $\pm S D(n=3)$, means followed by the same letter in a row do not significantly different $(\mathrm{p}<0.05)$.
으로 판단된다. 양배추 분말 첨가량을 달리하여 제조한 스 펀지 케이크의 외관 촬영 사진은 Fig. 1 과 같다.

\section{부피지수, 대칭성지수 및 균일성지수}

양배추 분말 첨가량을 달리하여 제조한 스펀지 케이크의 외관상 특성평가로 부피지수(volume index), 대칭성지수 (symmetry index) 및 균일성지수(uniformity index)를 측정 한 결과는 Table 4 와 같다. 부피지수는 대조구가 16.75 로 가장 높은 값을 보였고 양배추 분말 $5 \%$ 첨가구는 대조구와 유의적 차이를 보이지 않았으며 양배추 분말 첨가량이 증가 할수록 부피지수는 감소하는 경향을 보여 부피가 감소한 것을 알 수 있었다. 이러한 결과는 Table 2 의 반죽 비중의 변화와 밀접한 관계가 있으며 스펀지 케이크에 대체분말을 첨가함으로써 거품의 안정성이 떨어져 최종 부피가 감소하 는 것으로 판단된다.

대칭성지수는 케이크의 균형을 나타내는 것으로 양배추 분말 $10 \%$ 첨가구가 0.85 로 가장 높은 값을 보여 케이크의 중앙 부분이 평평하지 않고 돔 형태를 나타내는 것을 알 수 있으며 첨가량 증가에 따른 일정한 경향은 나타나지 않았다. 케이크의 좌우 치우침이 있는지를 보는 균일성지 수는 양배추 분말 첨가량이 증가함에 따라 유의적인 차이가 나타나지 않아 큰 영향을 미치지 않는 것으로 판단된다. 이러한 결과는 흑미가루를 첨가한 스펀지케이크의 품질특 성에 관한 연구(38)에서와 같이 첨가량이 증가할수록 대칭 성지수와 균일성지수가 일정한 경향을 보이지 않아 유의성 이 없는 것으로 보고된 결과와 유사하였다.

Table 4. Appearance characteristics of the sponge cakes containing different amounts of cabbage powder

\begin{tabular}{ccccc}
\hline & \multicolumn{4}{c}{ Cabbage powder content (\%) } \\
\cline { 2 - 5 } & 0 & 5 & 10 & 15 \\
\hline Volume index & $16.75 \pm 0.41^{\mathrm{al})}$ & $16.60 \pm 0.28^{\mathrm{a}}$ & $15.62 \pm 0.18^{\mathrm{b}}$ & $14.43 \pm 0.31^{\mathrm{c}}$ \\
Symmetry index & $0.75 \pm 0.15^{\mathrm{b}}$ & $0.73 \pm 0.08^{\mathrm{b}}$ & $0.85 \pm 0.11^{\mathrm{a}}$ & $0.62 \pm 0.09^{\mathrm{c}}$ \\
Uniformity index & $-0.23 \pm 0.05^{\mathrm{b}}$ & $-0.21 \pm 0.06^{\mathrm{b}}$ & $-0.27 \pm 0.08^{\mathrm{b}}$ & $-0.12 \pm 0.07^{\mathrm{a}}$ \\
\hline
\end{tabular}

${ }^{1)}$ Values are mean $\pm \mathrm{SD}(\mathrm{n}=3)$, means followed by the same letter in a row do not significantly different $(\mathrm{p}<0.05)$.

\section{비용적 및 굽기손실율}

양배추 분말 첨가량을 달리하여 제조한 스펀지 케이크의 비용적 및 굽기손실율을 측정한 결과는 Table 5와 같다. 케이크의 비용적은 양배추 분말 첨가량이 증가할수록 점차 적으로 감소하는 경향을 나타내었고 대조구와 5\% 첨가구 는 유의적 차이를 보이지 않았지만 $10 \%, 15 \%$ 첨가구는 유의적으로 감소하였다. 이러한 결과는 Jeong 등(39)의 파 프리카분말를 첨가한 스펀지 케이크 연구에서 파프리카 분말 대체분의 첨가량이 증가함에 따라 비용적은 감소하는 경향을 보였다는 연구의 결과와 유사하였다. 
굽기 과정의 손실은 주로 수분의 손실에 의한 것으로 케이크의 구조적인 변형을 일으키며, 또한 굽는 과정 동안 수증기의 팽창은 케이크의 부피를 증가시키고 케이크의 촉촉한 질감에 영향을 미치는 것으로 보고되었다 $(40,41)$. 스펀지 케이크의 굽기손실율은 대조구보다 양배추 분말 첨가구가 증가하는 것으로 나타났으며 $15 \%$ 첨가구가 8.20 으로 가장 높은 것으로 나타났다. 이러한 결과는 메생이 분말을 첨가한 스펀지 케이크의 품질특성(42)에서 대체분 말을 첨가함에 따라 스펀지 케이크의 반죽이 불안정하게 되고 이로 인해 생긴 크고 불규칙한 기공들 때문에 굽기 중 손실량이 증가한 것으로 보고되었으며, 본 연구에서 양

Table 5. Baking properties of the sponge cakes containing different amounts of cabbage powder

\begin{tabular}{ccccc}
\hline & \multicolumn{4}{c}{ Cabbage powder content (\%) } \\
\cline { 2 - 5 } & 0 & 5 & 10 & 15 \\
\hline Baking loss (\%) & $7.79 \pm 0.28^{\text {d1) }}$ & $7.85 \pm 0.23^{\mathrm{c}}$ & $7.93 \pm 0.35^{\mathrm{b}}$ & $8.20 \pm 0.28^{\mathrm{a}}$ \\
Specific volume (mL/g) & $3.98 \pm 0.15^{\mathrm{a}}$ & $3.93 \pm 0.17^{\mathrm{a}}$ & $3.62 \pm 0.13^{\mathrm{b}}$ & $3.57 \pm 0.12^{\mathrm{b}}$ \\
\hline
\end{tabular}

${ }^{1)}$ Values are mean \pm SD $(n=3)$. means followed by the same letter in a row do not significantly different $(\mathrm{p}<0.05)$.
배추 분말이 증가할수록 굽기손실율이 증가한 것으로 나타 난 것과 유사한 결과를 보였다.

조직감

양배추 분말의 첨가량을 달리하여 제조한 스펀지 케이크 의 텍스처를 측정한 결과는 Table 6과 같다. 경도에서 대조 구는 371.54 로 가장 낮게 나타났고 양배추분말 $5 \%$ 첨가구 와 유의적 차이가 없어 케이크의 경도에 영향을 미치지 않았지만 $10-15 \%$ 첨가구에서는 높은 경도 값을 보여 $5 \%$ 까 지 양배추분말 첨가구가 가장 적당할 것으로 보여진다. 이 러한 결과는 양배추분말을 첨가함으로써 케이크의 조직감 이 더 단단해짐을 알 수 있으며, 파프리카(39), 매생이 분말 (42)을 첨가한 스펀지 케이크의 연구결과와 같이 대체분말 의 첨가량이 증가할수록 경도 값이 증가하여 조직감이 더 단단해진다는 것과 유사한 경향을 보였다.

응집성은 대조구가 가장 높은 값을 나타내었고 양배추 분말 첨가량이 증가할수록 감소하는 경향을 나타내었다. 이러한 결과는 Kweon 등(4)이 스펀지 케이크에 김 분말 첨가 시 첨가량의 증가에 따라 응집성이 감소한다는 보고와

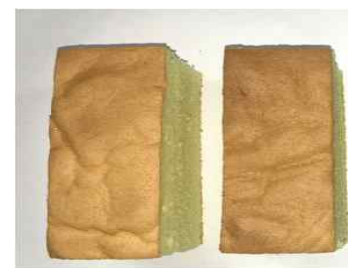

A

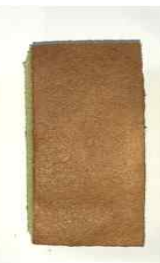

$\mathrm{C}$

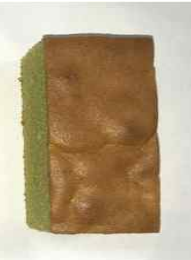

$\mathrm{D}$

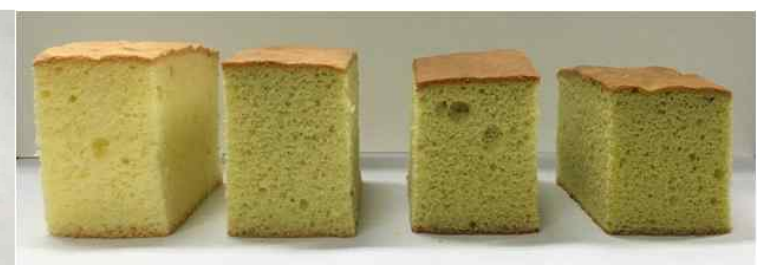

A
B
$\mathrm{C}$
D

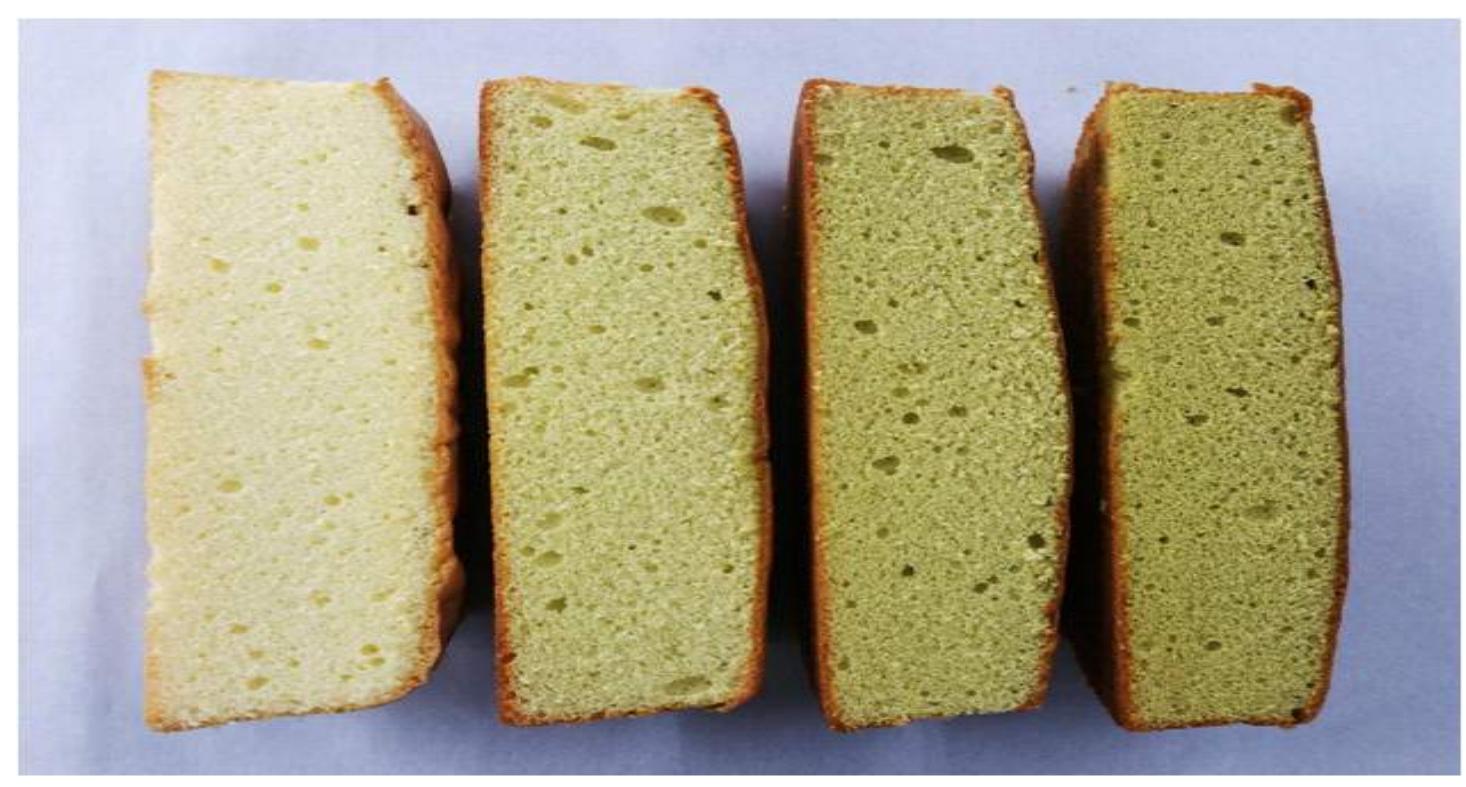

A

B

C

D

Fig. 1. Visual comparison of the sponge cakes that contained different amounts of cabbage powder. A, $0 \%$ cabbage powder added; B, $5 \%$ cabbage powder added; C, $10 \%$ cabbage powder added; D, $15 \%$ cabbage powder added. 
유사하였다. 반면 탄력성, 점착성, 부서짐성은 대조구와 $5-15 \%$ 첨가구는 유의적인 차이가 없는 것으로 나타났다.

Table 6. Textural properties of the sponge cakes containing different amounts of cabbage powder

\begin{tabular}{lcccc}
\hline & \multicolumn{4}{c}{ Cabbage powder content (\%) } \\
\cline { 2 - 5 } & 0 & 5 & 10 & 15 \\
\hline Hardness $\left(\mathrm{g} / \mathrm{cm}^{2}\right)$ & $371.54 \pm 8.95^{\mathrm{c} 1)}$ & $392.08 \pm 2.24^{\mathrm{c}}$ & $418.83 \pm 17.72^{\mathrm{b}}$ & $469.95 \pm 12.08^{\mathrm{a}}$ \\
Cohesivness (\%) & $58.43 \pm 0.78^{\mathrm{a}}$ & $56.50 \pm 2.32^{\mathrm{a}}$ & $51.05 \pm 8.23^{\mathrm{a}}$ & $40.03 \pm 0.96^{\mathrm{b}}$ \\
Springness (\%) & $\left.85.99 \pm 0.67^{\mathrm{NS} 2}\right)$ & $85.58 \pm 0.51$ & $82.93 \pm 2.70$ & $83.12 \pm 2.42$ \\
Gumminess (g) & $235.87 \pm 22.50^{\mathrm{NS}}$ & $210.04 \pm 19.88$ & $209.25 \pm 30.88$ & $208.94 \pm 18.32$ \\
Brittleness (g) & $202.72 \pm 17.88^{\mathrm{NS}}$ & $178.75 \pm 14.82$ & $173.07 \pm 21.44$ & $174.28 \pm 11.56$ \\
\hline
\end{tabular}

${ }^{1)}$ Values are mean \pm SD $(n=5)$, means followed by the same letter in a row do not significantly different $(\mathrm{p}<0.05)$.

${ }^{2} \mathrm{NS}$, not significant at the $5 \%$ level.

\section{항산화 활성}

양배추 분말의 첨가량을 달리하여 제조한 스펀지 케이크 의 항산화 활성을 측정한 결과는 Table 7과 같다. 페놀성 화합물은 자연계에 널리 분포되어 있는 2 차 대사산물의 하나로 2 개 이상의 수산기 $(\mathrm{OH})$ 를 가지고 있어 단백질과 같은 거대분자와 쉽게 결합하는 성질이 있으며 항암, 항산 화 및 심장질환 예방 효과 등의 생리활성 기능을 가지고 있다 $(43,44)$.

총 폴리페놀 함량은 대조구와 $5 \%$ 첨가구는 유의적 차이 를 보이지 않았으나 $15 \%$ 첨가구는 $40.97 \mu \mathrm{g} \mathrm{GAE} / \mathrm{mL}$ 로 가장 높은 값을 보였고 양배추 분말 첨가량이 증가할수록 총 폴리페놀 함량이 유의적으로 증가하는 결과를 보였다.

$\mathrm{DPPH}$ 라디칼 소거능은 항산화 활성을 측정하는 보편적 인 방법으로 페놀성 화합물과 같은 항산화 물질로부터 전자 나 양성자를 받아 안정한 분자로 환원될 때 보라색이 노란 색으로 탈색되는 것을 이용하여 다양한 기능성소재로부터 항산화 물질을 측정하는 방법으로 많이 이용되고 있다(45). 양배추 분말을 첨가한 스펀지 케이크의 DPPH 라디칼 소거 능은 대조구의 경우 DPPH 라디칼 소거능이 $86.33 \%$ 보였으

Table 7. Antioxidant activities of the sponge cakes containing different amounts of cabbage powder

\begin{tabular}{lcccc}
\hline & \multicolumn{4}{c}{ Cabbage powder content (\%) } \\
\cline { 2 - 5 } & 0 & 5 & 10 & 15 \\
\hline $\begin{array}{c}\text { Total polyphenol contents } \\
(\mu \mathrm{gg} G \mathrm{GA} / \mathrm{mL})\end{array}$ & $30.79 \pm 0.01^{\mathrm{cl})}$ & $31.00 \pm 0.01^{\mathrm{c}}$ & $34.39 \pm 0.01^{\mathrm{b}}$ & $40.97 \pm 0.01^{\mathrm{a}}$ \\
$\begin{array}{c}\text { DPPH radical scavenging } \\
\text { activity (\%) }\end{array}$ & $86.33 \pm 0.26^{\mathrm{c}}$ & $92.99 \pm 0.15^{\mathrm{b}}$ & $97.52 \pm 3.00^{\mathrm{ab}}$ & $99.32 \pm 0.53^{\mathrm{a}}$ \\
$\begin{array}{l}\text { Reducing power } \\
(\mathrm{OD} \text { at } 700 \mathrm{~nm})\end{array}$ & $0.15 \pm 0.00^{\mathrm{d}}$ & $0.49 \pm 0.01^{\mathrm{c}}$ & $0.54 \pm 0.01^{\mathrm{b}}$ & $0.82 \pm 0.02^{\mathrm{a}}$ \\
\hline $\begin{array}{l}1 \text { Values are mean } \pm \mathrm{SD}(\mathrm{n}=3), \text { means followed by the same letter in a row do not } \\
\text { significantly different }(\mathrm{p}<0.05) .\end{array}$
\end{tabular}

며 양배추 분말을 첨가구에서는 92.99-99.32\%로 대조구보 다 유의적으로 높게 나타났다( $\mathrm{p}<0.05)$.

환원력은 시료가 항산화제로서 사용될 수 있는 지표를 말하며, 측정은 ferric ion(Fe3+) 혼합물이 수소를 공여하여 ferrous $\left(\mathrm{Fe}^{2+}\right)$ 로 전환하는 능력을 $700 \mathrm{~nm}$ 에서 측정하여 흡광 도 값으로 나타낸 것(46)으로. 환원력은 대조구가 0.15 로 가장 낮고 양배추 분말 첨가량이 증가할수록 환원력이 0.49-0.82로 높게 나타나 유의적으로 증가하는 경향을 보 였다.

이러한 결과는 아마씨 분말을 첨가한 스펀지 케이크(47) 와 돼지감자분말을 첨가한 쌀 스펀지케이크(48) 연구에서 대체분말 첨가량이 증가할수록 $\mathrm{DPPH}$ 라디칼 소거능과 총 폴리페놀 함량이 유의적으로 증가한다는 보고와 유사한 경향을 보였다. 특히 대조구보다 5\% 첨가구에서 $\mathrm{DPPH}$ 라 디칼 소거능과 환원력이 급격히 높게 나타났으며 전반적인 항산화 활성 측정에서 양배추 분말을 첨가함에 따라 생리활 성을 나타내는 항산화 활성이 유의적으로 증가하는 결과로 이는 양배추 분말의 항산화제 성분이 영향을 미친 것으로 판단된다.

관능검사

양배추 분말 첨가량을 달리하여 제조한 케이크의 색상, 향미, 맛, 조직감 및 전체적인 기호도에 대한 관능검사 결과 는 Table 8 과 같다. 케이크의 색상에서 양배추 분말 $15 \%$ 첨가구가 4.72로 가장 낮게 나타났으며 대조구보다 5-15\% 첨가구가 유의적으로 낮은 선호도를 보였다. 향미는 양배 추 분말 5-15\% 첨가구가 대조구보다 유의적으로 낮게 나타 났으며 맛은 양배추 분말 5-15\% 첨가구가 대조구보다 높게 나타났으며 5\% 첨가구가 5.18로 가장 높은 선호도를 나타 내었다. 케이크의 조직감은 대조구보다 양배추 분말 5-15\% 첨가구가 감소하는 경향을 보였으며 $15 \%$ 첨가구는 4.35 로 가장 낮은 선호도를 나타내었다. 전체적인 기호도에서는 대조구와 양배추 분말 $10 \%$ 첨가구는 5.01 과 5.02 로 유의적 차이를 보이지 않았으나 $15 \%$ 첨가구는 4.53 으로 가장 낮은

Table 8. Sensory properties of the sponge cakes containing different amounts of cabbage powder

\begin{tabular}{ccccc}
\hline & \multicolumn{4}{c}{ Cabbage powder content (\%) } \\
\cline { 2 - 5 } & 0 & 5 & 10 & 15 \\
\hline Color & $5.43 \pm 0.35^{\mathrm{a} 2)}$ & $5.32 \pm 0.53^{\mathrm{b}}$ & $5.09 \pm 0.26^{\mathrm{c}}$ & $4.72 \pm 0.29^{\mathrm{d}}$ \\
Flavor & $5.12 \pm 0.56^{\mathrm{a}}$ & $4.93 \pm 0.32^{\mathrm{b}}$ & $4.54 \pm 0.56^{\mathrm{c}}$ & $4.30 \pm 0.35^{\mathrm{d}}$ \\
Taste & $4.96 \pm 0.34^{\mathrm{d}}$ & $5.18 \pm 0.27^{\mathrm{a}}$ & $5.10 \pm 0.33^{\mathrm{b}}$ & $5.04 \pm 0.32^{\mathrm{c}}$ \\
Texture & $4.91 \pm 0.42^{\mathrm{a}}$ & $4.67 \pm 0.26^{\mathrm{b}}$ & $4.50 \pm 0.54^{\mathrm{c}}$ & $4.35 \pm 0.36^{\mathrm{d}}$ \\
Overall acceptance & $5.01 \pm 0.25^{\mathrm{a}}$ & $4.93 \pm 0.23^{\mathrm{b}}$ & $5.02 \pm 0.33^{\mathrm{a}}$ & $4.53 \pm 0.72^{\mathrm{c}}$ \\
\hline
\end{tabular}

${ }^{11}$ Rate using a scale of $1-7$, where $7=$ excellent, $6=$ very good, $5=$ good, $4=$ fair, $3=$ poor, $2=$ very poor, $1=$ bad.

${ }^{2)}$ Values are mean $\pm \mathrm{SD}(\mathrm{n}=3)$, means followed by the same letter in a row do not significantly different $(\mathrm{p}<0.05)$. 
기호도를 나타내었다. 스펀지 케이크 제조 시 양배추 분말 의 첨가는 일정한 수준의 분말(5-10\%)을 대체할 때 맛과 전체적인 기호도를 향상시키거나 유지하는 것으로 나타났 으며 이는 건강기능성의 생리활성 측면을 긍정적으로 평가 한 것으로 사료된다. 이러한 결과는 브로콜리 분말(7)이나 무청 분말(9)을 첨가한 스펀지 케이크 연구 결과에서 대체 분말의 최적 첨가 비율은 $5 \%$ 로 제시하였으며 기능성효과 를 고려한다면 $10 \%$ 까지는 가능할 것으로 보고한 연구와 유사한 경향을 보였다.

\section{요 약}

양배추 분말 첨가량을 0-15\%로 달리하여 스펀지 케이크 를 제조하고 물리적 품질특성, 항산화 활성, 관능적 특성 및 제조적성을 조사하였다.

물리적 품질특성은 양배추 분말 첨가량이 증가할수록 반죽의 비중, 굽기손실율은 증가하였고, 케이크 crumb과 crust의 색도, 부피지수, 비용적은 감소하였다. 대칭성지수, 균일성지수는 대조구와 유의적인 차이가 없었다. 케이크의 경도는 양배추 분말 첨가량이 증가할수록 증가하였고, 응 집성은 감소하였으며 탄력성, 점착성, 부서짐성은 유의적 으로 차이가 없었다. 케이크의 항산화 활성을 나타내는 총 폴리페놀 함량, DPPH 라디칼 소거능, 환원력 등은 양배추 분말 첨가량이 증가할수록 증가하였다. 관능평가에서 색 상, 향미, 조직감은 대조구보다 양배추 분말 5-15\% 첨가구 가 유의적으로 낮은 선호도를 보였고 맛은 양배추 분말 $5 \%$ 첨가구가 5.18 로 가장 높은 선호도를 나타내었으며 전 체적인 기호도는 $10 \%$ 첨가구가 5.02 로 가장 높게 나타났다. 전반적인 품질특성을 조사한 결과는 양배추 분말 $5 \%$ 첨가 구가 비중, 부피지수, 비용적, 경도, 응짐성 등이 대조구와 유사한 경향을 보였고 생리활성 증가로 인한 항산화 활성과 맛에서 대조구보다 우수한 결과를 나타내었다. 이상의 결 과로 양배추 분말 첨가 스펀지 케이크 제조를 위한 양배추 분말의 첨가 범위는 5-10\%가 적절한 것으로 판단되었으며, 최적 첨가량은 $5 \%$ 인 것으로 나타났다.

\section{References}

1. Kim WM, Lee YS (2004) A study on the utilization state and the choice factors of the functional bakery products. Korean J Culinary Research, 10, 1-15

2. Lee KS, Kim SH (2007) Analysis of characteristics of the white bread with mixed vegetable powder. Korean J Hospitality Tourism, 16, 169-184

3. Chang HG (2004) Quality characteristics of sponge cakes containing various levels of millet flour. Korean J Food Sci Technol, 36, 952-958

4. Kweon BM, Jeon SW, Kim DS (2003) Quality characteristics of sponge cake with addition of laver powder. J Korean Soc Food Sci Nutr, 32, 1278-1284

5. Oh SC, Nam HY, Cho JS (2002) Quality properties and sensory characteristics of sponge cakes as affected by additions of Dioscorea japonica flour. Korean J Soc Food Cookery Sci, 18, 185-192

6. Jeong CH, Shim KH (2004) Quality characteristics of sponge cakes with addition of Pleurotus eryngii mushroom powders. J Korean Soc Food Sci Nutr, 33, 716-722

7. Kim CH, Cho KR (2010) Quality characteristics of sponge cakes made with different quantities of broccoli powder. Korean J Food Sci Technol, 42, 459-467

8. Lee SE, Lee JH (2013) Quality and antioxidant properties of sponge cakes incorporated with pine leaf powder. Korean J Food Sci Technol, 45, 53-58

9. Kim CH (2015) Quality characteristics of sponge cakes with radish leaf powder. J East Asian Soc Dietary Life, 23, 502-512

10. Chu YF, Sum J, Wu X, Liu RH (2002) Antioxidant and antiproliferative activities of common vegetables. J Agric Food Chem, 50, 6910-6916

11. Ferland G, Sadowski JA (1992) Vitamin K1 (phylloquinone) content of green vegetables: effects of plant maturation and geographical growth location. J Agric Food Chem, 40, 1874-1877

12. Cheney G (1952) Vitamin U therapy of peptic ulcer. Calif Med, 77, 248-252

13. Cheney G (1949) Rapid healing of peptic ulcers in patients receiving fresh cabbage juice. Calif Med, 70, 10-15

14. Jin TY, Oh DH, Eun JB (2006) Change of physicochemical characteristics and functional components in the raw materials of Saengsik, uncooked food by drying methods. Korean J Food Sci Technol, 38, 188-196

15. Cao G, Sofic E, Prior RL (1996) Antioxidant capacity of tea and common vegetables. J Agric Food Chem, 44, 3426-3431

16. Rice-Evans C, Miller N, Paganga G (1997) Antioxidant properties of phenolic compounds. Trends Plant Sci, 2, 152-159

17. Yang MO (2009) Quality characteristics of Sulgidduk added with cabbage powder. J East Asian Soc Dietary Life, 19, 729-735 
18. Kim GY, Yang MO (2010) Quality properties of Jeungpyun prepared with cabbage (Brassica oleracea var. capitata) powder. J East Asian Soc Dietary Life, 20, 291-298

19. Park BH, Cho HS (2006) Physicochemical characteristics of cabbage kimchi during fermentation. Korean J Soc Food Cookery Sci, 23, 600-608

20. Lee SH (2010) Effect of cabbage powder on baking properties of white breads. Korean J Food Preserv, 17, 674-680

21. Kim HJ (2015) Preparation of chiffon cake with cabbage powder and it's antioxidant activities. MS Thesis, Sunchon National University, Korea, p 1-45

22. Yi SY, Kim CS, Song YS, Park JH (2001) Studies on the quality characteristics of sponge cakes with addition of yam powders. J Korean Soc Food Sci Nutr, 30, 48-55

23. AACC (2000) Approved Method of the AACC. $8^{\text {th }}$ ed, Method 10-15, American Association of Cereal Chemists, St Paul, MN, USA

24. AACC (2000) Approved Method of the AACC. $8^{\text {th }}$ ed, Method 10-91, American Association of Cereal Chemists, St Paul, MN, USA

25. Pyler EJ (1979) Physical and Chemical Test Methods. Baking Science and Technology, Sosland Pub Co, Manhattan, KS, USA, p 891-895

26. Folin O, Denis W (1912) On phosphotungsticphosphomolybdic compounds as color reagents. J Biol Chem, 12, 239-243

27. Blois MS (1958) Antioxidant determination by the use of a stable free radical. Nature, 181, 1199-1200

28. Mau JL, Lin HC, Song SF (2002) Antioxidant properties of several specialty mushrooms. Food Res Int, 35, 519-526

29. Seo SJ, Choi YM, Lee SM, Kong SH, Lee JS (2008) Antioxidant activities and antioxidant compounds of some specialty rices. J Korean Soc Food Sci Nutr, 37, 129-135

30. Civille GV, Szczesniak AS (1973) Guidelines to training a texture profile panel. J Tex Stud, 4, 204-223

31. Pyler EJ (1988) Cake baking technology. In Baking Science and Technology, Vol $\Pi$, Sosland Pub Co, Merrian, KS, USA, p 992-998

32. Ellinger RH, Shappeck FJ (1963) The relation of batter specific gravity to cake quality. Baker's Digest Dig, 37, 52

33. Lee JH, Son SM (2011) Quality of sponge cakes incorporated with yacon powder. Food Eng Prog, 15,
269-275

34. Chung YS, Kim DJ (2009) Quality characteristics of sponge cake with pakchoi (Brassica compestris $\mathrm{L}$. ssp chinensis Jusl.) powder. J Korean Soc Food Sci Nutr, 38, 914-919

35. Kang MJ (2002) Quality characteristics of the bread added dandelion leaf powder. Korean J Food Preserv, 9, 221-227

36. Bennion EB, Bamford GST (1997) The technology of cake making. $6^{\text {th }}$ ed. Beny AJ (Editor), Blackie Academic \& Professional, London, England, p 275-288

37. Raidle MA, Klein BP (1983) Effects of soy or field pea flour substitution on physical and sensory characteristics of chemically leavened quick breads. Cereal Chem, 60, 367-370

38. Park YS, Chang HG (2007) Quality characteristics of sponge cakes containing various levels of black rice flour. Korean J Food Sci Technol, 39, 406-411

39. Jeong CH, Kim JH, Cho JR, Ahn CG, Shim KH (2007) Quality characteristics of sponge cake upon addition of paprika powder. Korean J Food Preserv, 14, 281-287

40. Berglund PT, Hertsgard DM (1986) Use of vegetable oils at reduced levels in cake, pie crust, cookies and muffins. J Food Sci, 51, 640-644

41. Paton D, Larocque GM, Horme J (1981) Development of cake structure influence of ingredients on the measurement of cohesive force during baking. Cereal Chem, 58, 527-532

42. Lee JH, Kwak EJ, Kim JS, Lee YS (2007) Quality characteristics of sponge cake added with Mesangi (Capsosiphon Fulvescens) powder. Korean J Soc Food Cookery Sci, 23, 83-89

43. Nakatani N (1990) Recent advances in the study on natural antioxidants. Nippon Shokuhin Kogyo Gakkaishi, 37, 569-576

44. Nozaki K (1986) Current aspect and future condition of phytogenic antioxidants. Fragrance J, 6, 99-106

45. Que F, Mao L, Zhu C, Xie G (2006) Antioxidant properties of chineses yellow wine, its concentrate and volatiles. LWT-Food Sci Technol, 39, 111-117

46. Sa YJ, Kim JS, Kim MO, Jeong HJ, Yu CY, Park DS, Kim MJ (2010) Comparative study of eletron donating ability, reducing power, antimicrobial activity and inhibition of a-glucosidase by sorghum bicolor Extracts. Korean J Food Sci Technol, 42, 598-604

47. Lee SY (2016) Quality characteristics of sponge cake added with flaxseed powder. MS Thesis, Hansung 
University, Korea, p 28-29

48. Kim MK, Lee EJ, Kim KH (2014) Effects of helianthus

tuberosus powder on the quality characteristics and antioxidant activity of rice sponge cakes. Korean J Food

Culture, 29, 195-204 